\title{
Occasional ilpotes.
}

\section{INTERNATIONAL NEUROLOGIGAL GONGRESS, BERNE, 1931 .}

At the instigation mainly of Dr. B. Sachs, of New York, who is well-known as one of the senior members of the neurological profession in the United States, a Committee representing the American Neurological Association sent out circulars to the chief countries of the world suggesting that an International Neurological Congress might with advantage to all concerned be called for 1931, and inviting consideration of the project. To this preliminary communication numerous responses were obtained, indicating unanimous approval of the plan. In accordance with a suggestion made by the Chairman of the American Committee, the great majority of the countries circularised appointed delegates, to form a Preliminary Organization Committee. This has since been constituted the Permanent Committee of Organization of the Congress, and it numbers some 100 or more members, each country having a representation of not more than six. The Council of the Neurological Section of the Royal Society of Medicine have appointed the following English neurologists on this Permanent Committee, and they form the English Committee: Sir James Purves Stewart (Chairman), Dr. Kinnier Wilson (Senior Secretary), Dr. W. J. Adie (Junior Secretary), Prof. Edwin Bramwell, Dr. Gordon Holmes, Dr. C. P. Symonds.

After considerable correspondence Berne was definitely selected as the place for the meeting of the Congress, which is to be in session from Monday, August 31st, to Saturday, September 5th, 1931.

The next step was the appointment of a Programme Executive Committee, consisting of not more than two members from each of the Committees of the countries concerned. This Programme Committee met in Berne on August 29th and 30th of this year, under the chairmanship of Dr. B. Sachs, who with Dr. Henry A. Riley represented America. The English members were Sir James Purves Stewart and Dr. Kinnier Wilson. Nearly fifty neurologists attended the meetings of the Programme Committee, including the following: Austria, Prof. O. Marburg and Prof. C. Economo; Belgium, Dr. L. Van Bogaert; Czechoslovakia, Prof. L. Haskovec and Dr. H. Prochazka; Denmark, Dr. K. H. Krabbe and Prof. A. Wimmer ; France, Prof. G. Guillain and Dr. G. Roussy ; Germany, Prof. O. Foerster and Prof. M. Nonne ; Holland, Prof. B. Brouwer and Prof. K. H. Bouman; Hungary, Dr. L. Benedek; Italy, 
Prof. O. Rossi and Dr. V. M. Buscaino ; Poland, Prof. J. Piltz and Dr. W. Sterling ; Russia, Prof. M. Kroll ; Spain, Dr. M. Prados ; Sweden, Prof. H. Marcus and Dr. N. Antoni ; Switzerland, Prof. R. Bing and Dr. C. Dubois. Roumania, Japan, and still other nationalities were duly represented.

Much important preliminary business was transacted by the Programme Committee. Dr. B. Sachs was unanimously elected President of the Congress, and the following eight Vice-Presidents, viz., Prof. Sir Charles Sherrington, and Profs. Bing, Kappers, Guillain, Marburg, Marcus, Nonne and Rossi. Among other appointments was that of Editor of the Transactions of the Congress, for which Prof. Brouwer of Amsterdam was nominated, with four colleagues, one for each of the official languages of the Congress, viz., Dr. Kinnier Wilson (English), Dr. G. Roussy (French), Prof. C. Economo (German), and Prof. V. Buscaino (Italian). After a great deal of discussion, owing mainly to the numbers of topics suggested by different countries, the following subjects were selected for consideration at the four chief sessions of the Congress :

1. Diagnostic and therapeutic procedures, surgical and otherwise, in brain tumours.

2. Muscle tonus : anatomy, physiology, and pathology.

3. Acute non-suppurative infections of the nervous system.

4. The rôle of trauma in the production of nervous symptoms.

In addition, it was decided that at least two afternoon sessions (and probably more) will be devoted to individual communications. For each of the four set discussions a Chairman was selected, and various names chosen as those of the opening contributors to them, each Chairman agreeing to be responsible for the final selection in respect of his own session. The essentially neurological character of the Congress was fully emphasized by the Programme Committee, and it was unanimously agreed to admit neuropsychiatric subjects to the programme list only in so far as they have a somatic basis.

As a mark of appreciation of their services to neurology a number of distinguished men were chosen to form a group of Honorary Members, included in which are Babinski, von Monakow, Pavlov, Ramon y Cajal, C. K. Mills, Dana, and Sir Henry Head.

The details of the hours of session, methods of raising funds, social aspects of the Congress, entertainment, publicity, were among other topics to which attention was directed. Messrs. T. Cook and Son were appointed official transportation agents for the Congress.

The meetings of the Programme Committee were characterised by cordiality and enthusiasm, auguring well for the success of the Berne Congress. Through the generosity of the American Neurological Association the whole of the members of the Committee, with their wives, were entertained to dinner at the close of the proceedings, and the spirit of international friendliness which then prevailed was particularly noticeable, amply fulfilling the hopes and justifying the aspirations of those with whom the idea of resuming such international conventions of the neurological profession originated. 